\title{
PERFIS DE ORFEU NA POESIA BRASILEIRA RECENTE
}

\section{PROFILES OF ORPHEUS IN RECENT BRAZILIAN POETRY}

\author{
Antônio Donizeti PIRES ${ }^{11}$
}

\begin{abstract}
RESUMO: Muitos são os atributos que perfazem o ciclo mítico de Orfeu, o mais importante dos poetas lendários da Grécia antiga: ele, além de amante devotado (pois desceu ao Hades em busca da amada Eurídice) e protótipo de poeta lírico (em termos ideais platônicos), teria sido o fundador do culto de mistérios que leva seu nome, o Orfismo.

Tema recorrente na literatura e nas artes ocidentais, sobretudo a partir das obras dos latinos Ovídio e Virgílio, o mito de Orfeu, em seus aspectos mítico-poéticos, vinca a poesia brasileira desde a Colônia e atinge inusitada voga a partir dos anos 40/50 do século XX, quando pode encharcar-se de certos aspectos místico-religiosas (Murilo Mendes; Dora Ferreira da Silva). Na contemporaneidade, os perfis de Orfeu continuam seu périplo pela poesia brasileira, em obras recentes de Adriano Espínola (Praia provisória, 2006), Geraldo Carneiro (Balada do impostor, 2006) ou Rodrigo Petronio (Venho de um país selvagem, 2009). A partir de tais obras tentar-se-á dar um corpo (embora metamórfico) ao contraditório Orfeu.
\end{abstract}

PALAVRAS-CHAVE: Poesia brasileira contemporânea; Poesia e mito; Orfeu e Orfismo; Análise e interpretação.

ABSTRACT: Many are the attributes that make up the mythical cycle of Orpheus, the most important legendary poet of ancient Greece: besides being a devoted lover (he descended into Hades to rescue his beloved Eurydice) and prototype of lyrical poet (in terms of platonic ideals), he is also said to have been the founder of the cult of mysteries named Orphism after him.

A recurring theme in western literature and arts, mainly after the Latin Ovid and Virgil's works, the Orpheus myth, in its mythicalpoetical aspects, is present in Brazilian poetry since the colonial period and reaches unexpected popularity from the $40 \mathrm{~s} / 50 \mathrm{~s}\left(20^{\text {th }}\right.$ century), when mystic-religious aspects were introduced (Murilo Mendes; Dora Ferreira da Silva). Nowadays, the profiles of Orpheus continue to be present in Brazilian poetry in recent works of Adriano Espínola (Praia provisória, 2006), Geraldo Carneiro (Balada do impostor, 2006) or Rodrigo Petronio (Venho de um país selvagem,

\footnotetext{
${ }^{11}$ Departamento de Literatura. Programa de Pós-Graduação em Estudos Literários - Faculdade de Ciências e Letras - Universidade Estadual Paulista (UNESP) - Araraquara - SP - CEP 14801-290 Brasil - adpires@fclar.unesp.br
} 
2009). Based on these works we aim to give the contradictory Orpheus a body (though metamorphic).

KEYWORDS: Brazilian contemporary poetry; Poetry and myth; Orpheus and Orphism; Analysis and interpretation.

\section{O primeiro Orfeu}

O "célebre Orfeu” é dos mais enigmáticos de todos os mitos do panteão grego. A começar por seu próprio nome, que Salomon Reinach, no começo do século XX, liga ao adjetivo grego orphnos, “[...] que significa obscuro.” (BRUNEL, 2005, p.766). Pierre Brunel, no verbete que escreve sobre Orfeu para o Dicionário de mitos literários, também enfatiza que o mito é por demais complicado, "[...] pois é um feixe de contradições." (p.766). Tal "feixe de contradições" parece advir "[...] das representações multifárias de Orfeu como poeta, músico, amante, herói, teólogo, adivinho, filósofo." (GAZZINELLI, 2007, p.32), conforme postula Gabriela Guimarães Gazzinelli em Fragmentos órficos.

Segundo os manuais de Mitologia (como o de Gama Kury, 1990), Orfeu, filho da musa Calíope e do rei trácio Éagro (ou filho de Apolo e de Calíope, em algumas versões), é o mais famoso e importante poeta lendário da Grécia ${ }^{12}$, cujo panteão inclui ainda Tâmiris, Museu, Lino, Aríon, Anfíon. O supremo canto de Orfeu (música e palavra) fazia com que os elementos da natureza, as feras e os homens parassem para ouvi-lo, seduzidos pelo divino dom do belo rapaz. Este aspecto mais geral completa-se com os quatro mitemas ${ }^{13}$ fundamentais que perfazem o ciclo mítico ${ }^{14}$ de Orfeu: a) a viagem ao lado dos Argonautas em busca do Velocino de Ouro, quando sua função é tanger a lira e cantar a fim de afastar as muitas ameaças da empreitada; b) o casamento infeliz com a ninfa Eurídice, pois esta, vitimada por uma serpente, logo lhe é usurpada

\footnotetext{
${ }^{12}$ Jacyntho José Lins Brandão (1990, p.26) afirma que a fonte mais antiga a referir-se a Orfeu é o poeta Íbico de Regió (séc. VI a.C.), "[...] o qual fala do onomaklytòn Orphén (fr.26, Adrados), isto é, do 'renomado Orfeu'." Consultar: BRANDÃO, J. J. L. O orfismo no mundo helenístico. In: CARVALHO, S. M. S. (Org.). Orfeu, orfismo e viagens a mundos paralelos. São Paulo: UNESP, 1990. p.25-34.

${ }^{13}$ Utilizo o conceito "mitema" para indicar cada um dos episódios que compõem o relato mítico. No caso de Orfeu, talvez o fundamental seja o terceiro (a descida do poeta ao Hades), mas o mito seria incompreensível sem a consideração dos outros três.

${ }^{14}$ A expressão "ciclo mítico" é inspirada em Pierre Grimal, que utiliza as variações "ciclo dos olimpianos" e "ciclos heroicos": nestes, estuda os heróis exemplares Hércules, Ulisses, Teseu e Jasão, mas não Orfeu, que é apenas referido como o companheiro cantor dos Argonautas (GRIMAL, 1983, p.68 e p.71). Consultar: GRIMAL, P. A mitologia grega. São Paulo: Brasiliense, 1983. p.42-96.
} 
pela morte; c) em decorrência, a catábase de Orfeu ao Hades, aonde vai para tentar reaver a esposa do mundo dos mortos: de fato, através da beleza de seu canto Orfeu consegue comover e demover os deuses infernais, Hades e Perséfone, que lhe devolvem a amada com a condição de que não olhe para trás (mas o poeta infringe o interdito, Eurídice desaparece nas trevas para sempre - a segunda morte de Eurídice, tão cantada pelos poetas - e Orfeu volta a terra desolado); d) finalmente, a própria morte do vate, estraçalhado pelas enciumadas bacantes da Trácia (a versão mais difundida).

Dos quatro mitemas, o primeiro (épico) foi tema e motivo de várias epopeias, como as anônimas Argonáuticas órficas e os poemas de Apolônio de Rodes ou de Valério Flaco; os outros três mitemas (mais líricos e dramáticos) nos legaram, desde o período helenístico grego, mas sobretudo a partir da obra dos poetas latinos Ovídio e Virgílio, uma pletora de poemas líricos, poemas dramáticos, dramas, tragédias, tragicomédias, comédias, contos, romances, óperas, pinturas, mosaicos, esculturas, filmes, histórias em quadrinhos...

\section{Orfeu, fundador religioso?}

Além do exposto, sempre de acordo com a tradição, Orfeu teria fundado o culto de mistérios que leva seu nome, o Orfismo: o fato, improvável segundo Brunel (2005, p.766), obscurece ainda mais a figura de Orfeu, pois é mais uma camada traiçoeira no terreno movediço que sustenta a biografia do poeta-amante.

Prática ritual, secreta e iniciática, o Orfismo difere do culto de Elêusis por ter deixado uma considerável tradição escrita e intelectual, que inclui tanto as inscrições tumulares e as fórmulas salvíficas (protopoemas órficos, dir-se-ia), quanto a redação de poemas cultuais (os anônimos Hinos órficos, atribuídos a Orfeu) e a interpretação e o comentário erudito de textos (comprova-o o "Papiro de Derveni”, encontrado apenas em 1962 e estudado por Gabriela Guimarães Gazzinelli, ao lado de outros documentos arqueológicos, em Fragmentos órficos). O Orfismo é tido como uma prática civilizatória e de conhecimento esotérico que, através de regras rígidas de conduta, rituais de iniciação e de purificação, estudos e conselhos para o post mortem, buscava aparelhar o homem para o bem-viver e para o bem-morrer. Dentre seus outros preceitos mais conhecidos estão o vegetarianismo, o culto da natureza e a proibição de derramamento de sangue, bem como a crença na metempsicose e na origem divina do 
ser humano, pois a salvação deste, após a morte, era o fim último das doutrinas órficas: por isso os iniciados eram sepultados com tabuinhas ou lâminas contendo fórmulas especiais que indicavam o reto caminho do reino da Bem-Aventurança.

Se a primeira referência literária ao mito de Orfeu aparece no séc. VI a. C., pode-se dizer que no séc. V a. C. já existe um movimento religioso órfico plenamente constituído, que adquirirá foros de universalidade e cosmopolitismo no período helenístico. O Orfismo, embasado em sua própria teogonia e cosmogonia, nem por isso excluía o ser humano, que na verdade estava no centro de seus interesses - por isso falase de uma antropogonia órfica, no sentido de que esta procurava revelar a origem mítico-divina do homem e também prepará-lo para a morte e para a busca da salvação além-túmulo. Neste sentido, o Orfismo é condizente com as filosofias do período voltadas para o ser humano (o Epicurismo e o Estoicismo), mas destas difere por voltarse para a alma, o mítico, o sagrado e a vida depois da morte.

Sobre a origem divina da humanidade, reportemo-nos a Apolo e Dioniso, os dois mais importantes deuses do Orfismo, notadamente pela relação dúbia que mantêm com Orfeu: este, filho de Calíope (uma das nove musas), de Apolo recebe o dom da música e da poesia. No entanto, os cultos órficos de mistério elegeram Dioniso como seu deus principal, talvez pelo fato de ele ter tido duplo nascimento e dupla vida: o primeiro Dioniso (ou Dioniso Zagreu, filho de Zeus e Perséfone) foi trucidado e devorado ainda menino pelos Titãs, e de seu coração salvo por Atena, segundo variantes, Zeus pôde fecundar Sêmele, a mãe do segundo Dioniso, o deus da vinha, da embriaguez, da inspiração e do teatro, como o conhecemos. Reza a lenda que dos restos misturados de Dioniso Zagreu e dos Titãs nasceram os homens, filhos do céu e da terra ao mesmo tempo. Em relação ao segundo Dioniso, sua prevalência nos rituais órficos talvez se deva à metamorfose simbólica que este deus representa, pois através da embriaguez, da inspiração e da supressão da razão, infundiria em seus adeptos o entusiasmo e a possessão divina, e este estar-com-o-deus (ou estar-no-deus) seria também preparatório para os fins últimos (salvacionistas) do Orfismo, embora os violentos rituais do culto dionisíaco contradigam a proibição de derramamento de sangue por parte dos órficos.

Por isso, aventa-se que somente por razões simbólicas o mito de Orfeu foi assimilado, nos mistérios órficos, ao antiquíssimo culto de Dioniso, cujas raízes estão na 
Grécia arcaica. Historicamente, pode-se levantar a hipótese de que nos sécs. VI-V a. C. o culto dionisíaco tenha passado por uma transformação radical, incorporando alguns mitemas (a catábase de Orfeu ao Hades, sobretudo) e os significados mais refinados do mito: o canto revelador e a música, a fidelidade e a dedicação amorosa, a sabedoria, a prerrogativa civilizatória. O mais correto, porém, é considerar que o Orfismo, como hoje o conhecemos, é de fato um culto novo, nascido nos sécs. VI-V a. C. sob os auspícios do poeta mítico, em cuja elaboração/condensação de princípios foram aproveitados (simbolicamente, insista-se) ritos tradicionais gregos (entre os quais, resquícios do culto dionisíaco) e de outras civilizações, bem como ensinamentos filosóficos, pretensões poético-literárias e a escolha de uma teogonia e uma cosmogonia específicas, bem diferentes da Teogonia de Hesíodo. Enfim, tudo isto evidencia o caráter letrado e intelectual do Orfismo, pois o afasta dos cultos de mistério tradicionais e o insere em seu próprio tempo histórico, tempo este já marcado (ao contrário do período arcaico) pelo extremo uso da razão e do questionamento filosófico. Assim, como culto religioso pessoal e cosmopolita, híbrido, sumamente preocupado com o ser humano (e não mais com os deuses intransigentes), o Orfismo foi um questionamento e uma crítica da religião oficial da pólis grega (por isso, aliás, encontrou o ápice de sua difusão durante o período helenístico e globalizado da cultura grega, a partir do séc. IV a. C.).

Reportando-nos novamente aos dois Dionisos, constata-se que ambos estão no centro dos cultos órficos devido a similaridades com a narrativa mítica de Orfeu (em seu quarto mitema). Pois a versão mais conhecida da morte de Orfeu reúne, sacra e ritualmente, os dois Dionisos: estraçalhado pelas bacantes da Trácia (as mulheres desvairadas que acompanham o segundo Dioniso), a morte violenta do poeta atualiza o esquartejamento do primeiro Dioniso, o Zagreu, pelos Titãs. E penso que o trabalho do poeta órfico, moderno e/ou contemporâneo, re-atualiza, sacra e ritualmente, o triplo acontecimento mítico e místico: exilado neste mundo vincado pela barbárie e consciente de sua dupla origem sagrada e profana (portanto, simbolicamente esquartejado), a voz poética que é revelação e capacidade poiética de se perfazer em canto (dons solares de Apolo), também encarna os mistérios cultuais noturnos dionisíacos, parte complementar do processo de construção e comunicação poética. 
Ambos os deuses, Apolo e Dioniso, amalgamados na estrutura essencial da poesia lírica e, claro, no próprio Orfismo, também estão atados de modo inextrincável no Fedro platônico, onde se discorre sobre as quatro manias ou loucuras divinas ${ }^{15}$ : a) a divinatória ou profética, dom de Apolo; b) a poética, atributo das musas (por sua vez, ligadas a Apolo); c) a mística ou mistérica, atribuída a Dioniso; d) a erótica, sob os auspícios de Afrodite e Eros, mas que também é inflamável nos rituais dionisíacos.

Assim, conforme Giorgio Colli em O nascimento da filosofia, Apolo e Dioniso reinam absolutos na esfera da loucura divina, esgotando-a. Em termos órficos, isto é da maior relevância, pois ressalta que as dúbias relações de Apolo e Dioniso com Orfeu devem precaver-nos contra uma visão simplista de conhecida dicotomia (que paga seu tributo à razão cartesiana): apolíneo (solar, artesão, racional) e dionisíaco (noturno, inspirado, emocional). A poesia de autores nossos como Murilo Mendes, Jorge de Lima (o caso mais exemplar, no Brasil, de amálgama dos postulados órficos e cristãos), Dora Ferreira da Silva e Rodrigo Petronio, entre outros, nega que tal caráter dicotômico seja estanque, mas sim interdependente e complementar, em mais de um sentido.

Devo assinalar, ainda, que a complexidade do mito de Orfeu e dos problemas a ele ligados, como a questão da poesia órfica e do Orfismo, têm-me levado (PIRES, 2009) a considerar que se pode pensar em pelo menos dois orfismos: um Orfismo místico-religioso e um Orfismo mítico-poético, mais estrito. O primeiro é resultante do culto de mistérios supostamente fundado por Orfeu e toca as raias do sagrado e do divino, do rito de iniciação e da escatologia, além de tingir-se de filosofia (principalmente a pré-socrática, a platônica e a neoplatônica) e de influenciá-la reciprocamente, ao menos nos primeiros tempos. Por seu turno, o Orfismo míticopoético, mais afeito ao relato mítico, englobaria não apenas aquelas produções poéticas atribuídas a Orfeu (os anônimos Argonáuticas órficas e Hinos órficos), mas a vasta produção literária (épica, lírica e dramática) que advém do mito e que teve larga fortuna no decorrer da cultura ocidental, até os dias de hoje. Na prática, talvez seja impossível demarcar a linha divisória entre um e outro Orfismo, no passado e no presente: a) no passado, porque as duas obras atribuídas a Orfeu são evidentemente anônimas, sendo que os Hinos órficos, de clara função ritual e propiciatória, são poemas dedicados aos deuses do panteão órfico - como estes, outros inúmeras poemas foram atribuídos ao

\footnotetext{
${ }^{15} \mathrm{O}$ filósofo, pela boca de Sócrates, pouco discorre sobre a loucura humana, que coloca no simples plano das enfermidades físicas.
} 
poeta lendário, talvez porque seu nome era garantia de autoridade e conhecimento público; b) no presente, porque há poetas que deliberadamente confundem, em seu trabalho, crenças órficas aliadas à tematização de aspectos do ciclo mítico de Orfeu ou que imiscuem tais crenças ditas pagãs a crenças católico-cristãs (em nosso caso, Murilo Mendes, Jorge de Lima, Dora Ferreira da Silva e Rodrigo Petronio estão entre estes); outros há que não abraçam os postulados órficos, mas em dado momento de sua obra se voltaram para o problema (Carlos Drummond de Andrade nos anos 50; Dante Milano; a tragédia carioca de Vinicius de Moraes); outros há, ainda, que apenas se valem do mito de Orfeu (ou de Orfeu e Eurídice) como tema e motivo de suas obras (sendo mais comum no período clássico-colonial, nem por isso deixa de surgir no séc. $\mathrm{XX}$, como nas árias dedicadas por Péricles Eugênio da Silva Ramos à morte de Orfeu).

Em geral, pode-se dizer que o Orfismo místico-religioso está mais estudado (pois é interdisciplinar e envolve saberes hauridos da Mitologia, da Religião, da História, da Antropologia, da Arqueologia, da Literatura e das Artes iconográficas etc.), e que o Orfismo mítico-poético tem sido estudado principalmente do ponto de vista da Literatura Comparada, por autores que se preocuparam em rastrear, nesta ou naquela literatura, a presença do mito de Orfeu (ou Orfeu e Eurídice) apenas como tema e motivo, neste ou naquele período literário (por exemplo, o estudo de Pablo Cabañas, El mito de Orfeo en la literatura española, $1948^{16}$, ou o de H. B. Riffaterre, L'Orphisme dans la poésie romantique, $1970^{17}$ ). Faltam, portanto (principalmente no Brasil), estudos que busquem aproximar devidamente as duas formas de Orfismo e que evidenciem seus pontos de contato e de repulsão.

Tal lacuna é suprida, em grande parte, pela obra organizada por Alberto Bernabé e Francesc Casadesús, intitulada Orfeo y la tradición órfica: Un reencuentro ${ }^{18}$, publicada na Espanha em 2008: seus dois volumes, com quase 2000 páginas, reúnem pesquisadores de várias nacionalidades e oferecem perspectivas atualizadas do problema candente do Orfismo e de suas intrincadas relações com a Filosofia; com a Escatologia, a Religião, a Magia e a Mitologia; com a Antropologia e a Arqueologia; com a História e a Geografia; com a Poesia, a Literatura e as artes iconográficas

\footnotetext{
${ }^{16}$ CABAÑAS, P. El mito de Orfeo en la literatura española. Madrid: Consejo Superior de Investigaciones Científicas, 1948.

${ }^{17}$ RIFFATERRE, H. B. L'Orphisme dans la poésie romantique. Paris: Nizet, 1970.

${ }^{18}$ BERNABÉ, A.; CASADESÚS, F. (Coords.). Orfeo y la tradición órfica: un reencuentro. Madrid: Akal, 2008 (2 v.).
} 
(pintura, escultura, mosaico, cerâmica...). Os estudos são da maior importância porque enfatizam que a milenar questão órfica (inclusive aquela ligada à poesia lírica), na sua complexidade, alimenta-se de problemas intrincados como mito e religião, paganismo e cristianismo, hermetismo e idealismo, poesia e música, conhecimento esotérico e conhecimento filosófico: tal amálgama intrincado tem como característica básica, na modernidade, não apenas a presença luminosa de Orfeu como símbolo do poeta lírico (que é, desde o Romantismo-Simbolismo, demiurgo, vate, profeta, tradutor, Iniciado, Eleito...), mas como índice de resistência do artista decaído que, mesmo sem função na alienante sociedade capitalista, apropria-se do mito (inclusive degradando-o) para evidenciar o seu conhecimento e a sua aptidão únicos, sem paralelo entre os bens de consumo imediatamente úteis.

\section{Uns novos perfis de Orfeu}

O ciclo mítico de Orfeu atinge inusitada voga no Brasil a partir dos anos 40/50 do século XX, motivada talvez pela maior divulgação dos poetas Fernando Pessoa e Rainer Maria Rilke entre nós. Na contemporaneidade estilhaçada, os perfis contraditórios de Orfeu continuam seu périplo pela poesia brasileira, em obras recentes de poetas tão díspares entre si como Geraldo Carneiro (Balada do impostor, 2006), Adriano Espínola (Praia provisória, 2006) ou Rodrigo Petronio (Venho de um país selvagem, 2009). Cada um a seu modo, continuam a dar corpo ao lendário Orfeu e a dotá-lo de novos e imprevistos significados, como se verá.

Adriano Espínola e Geraldo Carneiro são da mesma geração, nascidos ambos em 1952: Espínola, em Fortaleza; Carneiro, em Belo Horizonte. Ambos vivem no Rio de Janeiro, sendo que Espínola, formado em Letras, é doutor pela UFRJ com tese defendida sobre Gregório de Matos: professor universitário, ensinou na UFC e atualmente trabalha, como professor-visitante, na UFRJ. Por seu turno, Carneiro ligouse desde cedo à MPB e ao teatro: a rápida apresentação do autor, na antologia 26 poetas hoje, de Heloisa Buarque de Hollanda, o dá como "Estudante de Letras e letrista de música popular." (HOLLANDA, 1976, p.205), já com um livro publicado àquela altura, Na busca do sete-estrelo, mas não pude averiguar se nosso poeta concluiu o curso de Letras. Seja como for, sua estreia dá-se pelos anos 70, e embora não seja tão famoso quanto Chacal ou Cacaso, talvez possa ser ligado ao movimento amplo da Poesia 
Marginal carioca. Ligação arbitrária, decerto, mas que nos serve, neste momento, para situá-lo e à sua obra, que paga tributo ao humor e ao coloquialismo, ao prosaísmo, ao rebaixamento do mito e à certa mistura de poesia e vida, em atitude performática. Evidente que esta generalização precisa ser revista, inclusive porque a poesia completa de Geraldo Carneiro acaba de ser publicada, e também porque chama a atenção o modo reiterado como Orfeu - ou Orfeu e Eurídice - transita pelos mais diversos livros do autor. Para esta ocasião, vejamos apenas o poema "Orfeu revisitado" (republicado, em Balada do impostor, na seção "Juízo final", que fecha o livro; já aparecera na terceira obra de Carneiro, Piquenique em Xanadu, 1988, na seção “carnavais”):

\author{
"Orfeu revisitado" \\ eu, Orfeu, me demito \\ não tenho gás nem savoir-faire de mito \\ a musa me deixou no rádio-táxi \\ bandeira 2 na porta do Parnaso \\ (chamei o Criador ao telefone: \\ Oh Zeus: what the Hell \\ Am I doing in Paradise?) \\ perdi meus verdes anos na ilusão \\ de ser o mais perfeito semideus \\ da nova geração: e agora, Orfeu? \\ Eurídice partiu com o Minotauro \\ e se perdeu no carnaval de Creta \\ Penélope, a paixão secreta, \\ não esperou o The End da Odisséia \\ e foi passar o último weekend \\ nos subúrbios de Pompéia \\ e agora, Orfeu? \\ o que fazer senão espairecer \\ ser e não-ser o coração romântico \\ de Tróia \\ sonhando precipícios \\ ao sol de um balneário de quimeras?
}

(CARNEIRO, 2006, p.90).

O poema (em longos versos livres e brancos, em estrofe única de rimas ocasionais) faz uma miscelânea de mitos clássicos gregos, de obras literárias gregas e de várias culturas e civilizações, antigas e contemporâneas, como a indicar que é dos cacos das várias tradições, embaralhadas, que ele se nutre. Porém, a tradição é um peso que esmaga o eu-lírico, que então se recusa a ocupar o lugar (a representar o papel) de poeta 
luminar, prototípico, que tem cabido ao lendário Orfeu. E é através do humor e da ironia, do rebaixamento do legado clássico e da mistura de registros elevados e baixos (formais, linguísticos, de conteúdo) que o poeta afasta de si a ilusão e a tentação "de ser o mais perfeito semideus / da nova geração", negando-se à alta função e com isso renegando-a. Porém, atente-se para o fato de que a voz lírica, ao invés de lamentar a perda de função do poeta na sociedade contemporânea, ou a perda da aura, ou o divórcio entre poesia e sociedade (como faria um poeta mais propriamente moderno), vale-se de coisas caras a esta mesma sociedade (carnaval, anglicismo, consumismo, subúrbio, balneário, rapidez de comunicação, verniz cultural, turismo, conhecimento apenas informacional, superficial e barato) para legitimar a sua demissão da condição de mito. Por outro lado, pode-se considerar que o poeta demite-se dessa condição porque, além de não aprovar sua massificada realidade social, também não concordaria com seu momento presente, imediatamente pós-ditadura militar (o poema aparece em 1988): ou seja, o poeta não se quer arauto de um regime desprezível, e por isso se desqualifica ao desqualificar o passado mítico. Assim, o reiterado "E agora, Orfeu?", com que o sujeito lírico dialoga com o conhecido poema de Drummond, não quer dizer que o homem comum, histórica e socialmente condicionado, foi substituído pelo mito atemporal, mas que o poeta, novo Orfeu irremediavelmente mergulhado num tempo-espaço sempre problemático, não tem como se eximir de responsabilidade ética e política. Finalmente, em termos estéticos, a ironia se adensa porque a voz lírica alardeia sua suposta falta de tato e preparo, pois não tem "gás" (inspiração) ou "savoir-faire" (conhecimento e habilidade, mas também esperteza e astúcia, o que pode incluir o específico conhecimento poético, em seus vários graus): ora, são justamente o "gás" e o "savoirfaire" que fazem com que o eu-lírico possa embaralhar, lúdica e ironicamente, os vários registros de seu poema (em moldes ainda devedores do ponto de vista amplo da Poesia Marginal, mas também daquele Modernismo que lhe serve de base: o de Oswald de Andrade ou o de Manuel Bandeira). Isto, ao mesmo tempo em que leva o sujeito lírico ao gozoso "espairecer", o dota de um desconcertante e concomitante "ser e não-ser", a revelar-lhe (e a revelar-nos) a ambiguidade específica da poesia lírica, em geral, e a do poema em apreço - o que, em última instância, é espelho do "mundo misturado" e do "mundo caduco" no qual o poeta (Orfeu rebaixado) está fadado a viver. Em suma, as várias questões formais e de conteúdo, brevemente pinçadas e comentadas, ainda que 
muito generalizantes, dão a ver o estilo e a herança maior da poesia de Geraldo Carneiro.

Muito diferentes são a obra e o tratamento dado a Orfeu por Adriano Espínola, cujo trabalho poético surge em 1981, com Fala, favela, e prossegue com O lote clandestino (1982), Trapézio (1984), Táxi (1986), Metrô (1993), Em trânsito: Táxi/Metrô (1996; 2a edição), Beira-sol (1997) e Praia provisória (2006). Poeta requintado, herdeiro das experiências e do rigor construtivo modernistas, nem por isso Espínola desdenha a tradição do verso, do metro e da forma fixa (o soneto decassílabo, o hai-cai), explorando em seu trabalho tanto os temas metafísico-existenciais quanto os sociais e contingentes. O poeta é, segundo Domício Proença Filho, "Cultor de uma poesia inquietamente multifacetada, marcadamente original, feita de imagens e ritmos múltiplos [...]" (PROENÇA FILHO, 2006, p.17), cujo modus operandi pode ser flagrado no poema abaixo, de rara beleza e concisão construtivo-polissêmica:

"Orfeu"
dilacerado
(pelas trácias
do tempo)
o arco arcaico do meu peito
no entanto
se retesa
e soa
outra vez
(noutra voz)
vário
no leito
do canto
que não cessa
visionário

(ESPÍNOLA, 2006, p.49).

O poema, ainda que em curtos versos livres e brancos, é vincado pelo rigor construtivo e pela intensa sonoridade, cujo apoio aliterativo está nas sibilantes ("s", "ss", “c", "z") e na fricativa "v", ao lado das assonâncias e rimas do "a" aberto, seguido de perto pelo "e" e pelo "o" também abertos. Dir-se-ia que as quatro estrofes de 4-3-3-4 
versos se espelham e se abismam, pois se tem um quarteto, dois tercetos e novamente um quarteto, como a indicar o movimento do eu poético contemporâneo em direção à origem e ao mito. Por isso, a disposição estrófica leva a pensar que tal movimento é positivo, de filiação e de afirmação da voz poética atual em relação a seu modelo arquetípico, pois não se tem, no poema, a depreciação do mito de Orfeu e das coisas que lhe dizem respeito. Entretanto, seja dito que o texto, ao filiar-se à lendária tradição, faz questão de marcar sua diferença em relação ao modelo: assim, o poema, marcado pela síntese e pela concisão extremas, valoriza sobremodo o poeta e sua individualidade, e, por extensão, a fragmentada subjetividade lírica moderno-contemporânea e a configuração de um eu problemático ("vário", dotado de "outra voz", "visionário"), que, no entanto, ainda canta e escreve mesmo ameaçado "pelas trácias / do tempo". A efusão da subjetividade problemática talvez destoe do rigor compositivo do texto, que por imposição moderna se quereria mais impessoal e ausente: entretanto, tal recuperação da voz que fala e de sua configuração no corpo e nos vários estratos significativos do poema tem sido uma recorrência importante na poesia mais atual.

A composição de Espínola, se nos reportamos ao ciclo mítico de Orfeu, valoriza o quarto mitema com que o caracterizei, pois parte da imagem da morte de Orfeu, esquartejado pelas bacantes da Trácia, para refletir acerca do poeta presente: como se sabe, Orfeu morto tem seus pedaços recolhidos por Apolo, mas sua cabeça, sempre cantando, é levada pela corrente do rio Hebro, atinge o mar e finalmente chega às praias da ilha de Lesbos, onde lhe rendem homenagens fúnebres e erguem monumentos em sua memória. Ora, o poeta presente também foi estraçalhado em sua integridade, pois tem "o arco arcaico do meu peito" "dilacerado" "pelas trácias / do tempo", embora tal arco esteja tensionado e ressoando (“outra vez", "noutra voz”, "vário”, "visionário”) "no leito / do canto / que não cessa". O adjetivo "trácias" refere-se, no poema, à origem das bacantes que assassinaram violentamente Orfeu, mas é possível questionarmos, a partir da metáfora, que novas "trácias" são essas que subjugam e ameaçam a integridade do poeta e do poema, nos tempos sombrios que correm. Também é possível, pelo parentesco sonoro, lermos na expressão adjetiva e metafórica as "traças" e os "traços" do tempo, a marcar e a corroer a trajetória, a memória e a integridade do poema e do poeta. Os versos requerem ainda uma aproximação com o geral do poema de Geraldo Carneiro, uma vez que essas novas "trácias" (traças) a ameaçar contínua e 
cotidianamente o poema e o poeta, e a constrangê-los, podem ser a sociedade massificada, a política eleitoreira, a degradação e o consumo acrítico do mito, a corrosão dos valores. Num caso como no outro, a palavra de ordem é "resistência" (pensemos em Alfredo Bosi), seja aderindo irônica e falsamente à futilidade vã da sociedade atual (Carneiro), seja afastando-se dela e compondo poemas de requintada e elevada carpintaria (Espínola).

Enfim, na estrutura do poema de Espínola os versos "(pelas trácias / do tempo)" estão entre parênteses (primeira estrofe), bem como a fala do poeta atual, "(noutra voz)" (terceira estrofe), como a indicar que o trabalho das trácias (das traças) e do poeta são similares, pois calcados na transformação ritual, na prática intertextual, no aproveitamento dos vários palimpsestos da cultura, na corrosão dos cacos e restos da tradição. Com isto, a composição de Espínola é perpassada por requintado matiz metapoético e metalinguístico, que então a insere numa tradição mais reflexiva, artesanal e cerebral da poesia moderno-contemporânea, diferente daquela abraçada por Geraldo Carneiro, poeta talvez mais instintivo e mais inspirado.

O paulista Rodrigo Petronio, nascido em 1975, é o mais jovem dos três poetas que aqui se perfilam ao lado de Orfeu: formado em Letras Clássicas e Vernáculas pela USP, Petronio estreou em 2000, com História natural, ao qual se seguiram Pedra de luz (2005) e Venho de um país selvagem (2009). Sua pequena mas densa obra chama a atenção, entre outros motivos, pelo sólido conhecimento poético e filosófico do autor, pelo manejo das formas tradicionais, das formas livres e dos ritmos da poesia em vernáculo, pela busca esmerada do sagrado e de suas manifestações simbólicas, pela requintada ejaculação barroco-surrealista de imagens que alimenta seu trabalho, pela recusa da velha razão cartesiana e pelo cansaço da novidade vanguardeira a qualquer custo. Do último livro de Petronio (composto por poemas mais curtos do que o anterior, Pedra de luz), pincemos o declaradamente órfico

"Não conheço teu corpo: habito tua voz"

Não conheço teu corpo: habito tua voz.

A noite é um som de galhos e se quebra.

Desperta o minério. Sonha alada dentro do cristal.

Abriga nossas faces. Desfaz toda distância.

Suprime o espaço que vai da ideia à treva.

Clareira e vazante. Esta foz nos precede. 
A água gera uma água inaugural em sua taça.

És tu, pedra enredada entre as mãos das ervas.

Onde esculpo teu rosto feito de carícia e tempo.

Aqui vivemos o despertar da carne, presa e pétala.

Iluminados irrigamos estas árvores, somos sua linfa.

A madrugada tranquila, verde tergal, sonho aberto

Verga-se sobre os confins de nossos corpos e das éguas que movem a Terra.

Sorvidos em um movimento puro, ela nos rega.

Assim a eternidade se entrelaça em nós.

Assim a plenitude não nos basta:

Animais, extraímos luz da luz na selva.

(PETRONIO, 2009, p.50).

O poema também é construído em longos versos livres e brancos e em estrofe única de rimas ocasionais (toantes), como o de Carneiro, mas se está muito longe da cosmovisão que embasa a poesia do "marginal" mineiro-carioca. E se está também muito distante do rigoroso e cerebral processo construtivo de Espínola, pois o poema de Petronio, ao primar pelo acúmulo de imagens e pelo esmero rítmico-semântico de cada verso em particular (em detrimento do todo do texto, cuja compreensão fica comprometida), explora amiúde um símbolo que lhe é caro (a água; aqui de permeio com a terra e a noite). Já no primeiro verso do poema, a declaração peremptória "Não conheço teu corpo: habito tua voz." merece três considerações: a) revela que se está no terreno do mito (e, como já disse Fernando Pessoa, "O mito é o nada que é tudo." PESSOA, 1998, p.23), daí a impossibilidade de dar-lhe um corpo ou de re-conhecer-lhe qualquer materialidade - a não ser o simbólico corpo-água de Orfeu, sempre vário e sempre sujeito à metamorfose proteica; b) liga a poesia ao mito, pois ambos agem como fundação e explicação do mundo; c) procede à filiação do próprio poeta que fala a Orfeu, pois é pela voz, pelo canto, pela poesia que é possível estabelecer, renovar e manter a ancestral relação. Além disso, o poema representa, claramente, uma adesão incondicional do artista aos princípios do Orfismo místico-religioso, sob o primado de Dioniso, ao contrário dos outros dois poemas, que se perfazem como exemplos do orfismo mítico-poético mais estrito. Enfim, o poema de Petronio aproxima-se de certa tradição da lírica luso-brasileira preocupada com o sagrado e o sublime e com a exploração, no verso, dos movimentos amplos da alma e da busca metafísica, calcados em forte imagética de herança surrealista - ou barroco-surrealista, como já se afirmou: assim, não é estranho ao jovem poeta o trabalho de Foed Castro Chamma, Dora Ferreira 
da Silva, Murilo Mendes, Jorge de Lima, Roberto Piva ou Claudio Willer, entre nós, ou de portugueses como Herberto Helder e António Ramos Rosa.

À guisa de conclusão, registre-se que a obra em progresso dos três poetas, Geraldo Carneiro, Adriano Espínola e Rodrigo Petronio, irmana-se ao recuperar, para a nossa contemporaneidade esfacelada, os restos do também esquartejado Orfeu, que por isso permanece como representação simbólica válida de nosso próprio tempo. Por outro lado, o tratamento sintático e rítmico-semântico que os três conferem a seus poemas é muito diferente, o que poderia nos levar a refletir, apesar do risco da generalização, que as três maneiras perfariam três modos básicos da poesia brasileira mais contemporânea, na perspectiva, por exemplo, de um Domício Proença Filho. Contudo, como este é um ensaio também em progresso, de aproximação da obra dos três poetas, é mister que consideremos, apenas, que os três parecem muito preocupados com o tratamento pessoal do verso, para além desta ou daquela tendência dominante, e para além de uma concepção escolar ou periodológica de verso e metrificação. Quer-se dizer que, sendo o verso o esteio básico da poesia lírica (em forma fixa ou livremente construída), está-se ainda sob o efeito daquela crise de vers depreendida por Mallarmé em 1897: crise esta não superada pelo Concretismo e pela chamada poesia visual-experimental, mas que continua a nutrir os poetas mais interessantes de nossa época. E nada mais significativo, para estes, do que problematizar o próprio patrono da Lírica (o digníssimo Orfeu) na crise e na crítica que o verso instaura e re-instaura a cada novo poema.

\section{REFERÊNCIAS}

BERNABÉ, A.; CASADESÚS, F. (Coords.). Orfeo y la tradición órfica: un reencuentro. Madrid: Akal, 2008 (2 v.).

BOSI, A. Poesia resistência. In: O ser e o tempo da poesia. São Paulo: Cultrix, 1997. p.139-192.

BRANDÃO, J. J. L. O orfismo no mundo helenístico. In: CARVALHO, S. M. S. (Org.). Orfeu, orfismo e viagens a mundos paralelos. São Paulo: UNESP, 1990. p.25-34.

BRUNEL, P. (Org.). Dicionário de mitos literários. 4.ed. Rio de Janeiro: J. Olympio, 2005.

CABAÑAS, P. El mito de Orfeo en la literatura española. Madrid: Consejo Superior de Investigaciones Científicas, 1948. 
CARNEIRO, G. Balada do impostor. Rio de Janeiro: Garamond, 2006.

ESPÍNOLA, A. Praia provisória. Rio de Janeiro: Topbooks, 2006.

GAMA KURY, M. da. Dicionário de mitologia grega e romana. Rio de Janeiro: Jorge Zahar, 1990.

GAZZINELLI, G. G. (Org. e trad.). Fragmentos órficos. Belo Horizonte: UFMG, 2007.

GRIMAL, P. A mitologia grega. São Paulo: Brasiliense, 1983.

HOLLANDA, H. B. de. 26 poetas hoje. Rio de Janeiro: Labor, 1976.

[ORFEU]. Argonáuticas órficas. Himnos órficos. Introducciones, traducciones y notas de Miguel Periago Lorente. Madrid: Gredos, 1987. p.63-247 (Biblioteca Clásica Gredos, 104).

PESSOA, F. Mensagem. Organização Fernando Cabral Martins. São Paulo: Companhia das Letras, 1998.

PETRONIO, R. Venho de um país selvagem. Rio de Janeiro: Topbooks, 2009.

PIRES, A. D. O obscuro e 'renomado Orfeu' \& problemas iniciais do orfismo. In: VOLOBUEF, K. (Org.). Anais do I Colóquio Vertentes do Fantástico na Literatura [2009]. Araraquara, SP: Laboratório Editorial, 2009. p.341-368.

PROENÇA FILHO, D. Poesia brasileira contemporânea: multiplicidade e dispersão. In:_ _ (Org.). Concerto a quatro vozes: Adriano Espínola, Antonio Cícero, Marco Lucchesi, Salgado Maranhão. Rio de Janeiro/São Paulo: Record, 2006. p.7-18.

RIFFATERRE, H. B. L'Orphisme dans la poésie romantique. Paris: Nizet, 1970.

Artigo recebido em 21/06/2011

Aceito para publicação em 02/08/2011 